\title{
“A STUDY ON INVESTMENT BEHAVIOUR AMONG INVESTORS WITH SPECIAL REFERENCE TO BANGALORE CITY"
}

\author{
DR. S. AMUDHAN ${ }^{1}$, DR. J. POORNIMA ${ }^{2}$ \& DR. B. SENTHIL ${ }^{3}$ \\ ${ }^{1}$ Assistant Professor, Commerce and Management, St. Joseph's College (Autonomous), Bangalore, India \\ ${ }^{2}$ Assistant Professor, Department of Management Studies, Jain (Deemed-to-beUniversity), Bangalore, India \\ ${ }^{3} \mathrm{HoD}$ of Commerce, KSR College of Arts and Science for Women, Namakkal, India
}

\begin{abstract}
This paper plans to examine the reserve funds goals, investors behaviour, and risk tolerance level of private, government and self-employed in Bangalore city. An well administered questionnaire has been utilized to know di $\square$ erent parts of investors on their investment behaviour and factors influencing. Chi square and ANOVA statistics tool has been applied to check the association between Occupation, income level and qualification, age and investment behaviour, factors influencing investors. The examination finds that measure of investment depends upon the income level of investors and investment experience comes through time. It is additionally seen that investors spare in a taught way and are very levelheaded and wary in managing their well-deserved reserve funds. Far-located objectives and worry for future prosperity invigorate their reserve funds propensity.
\end{abstract}

KEYWORDS: Investment behaviour, Equity, Commodity, FOREX, Savings, Investment, Risk \& Return

Received: Jun 09, 2020; Accepted: Jun 29, 2020; Published: Jul 25, 2020; Paper Id.: IJMPERDJUN2020459

\section{INTRODUCTION}

Familiarity with investment roads and money related market assumes a vital job in the decision of venture openings. High-cash investors consistently lead an examination before putting resources into a portfolio.Presently, investors have immense information about the different venture exercises and they incline toward different venture roads as indicated by their decision or targets and money related position. Investors make a colossal commitment to their economy worldwide.In the present situation individual investors assume a crucial job in progress of a nation, they can possibly change their own monetary status, just as that of the networks and nations in which they live.

The creating nations in world, like India face as observed the huge errand of finding adequate cash-flow to use in their advancement endeavours. A large portion of nations think that its troublesome at stage to escape the endless loop of neediness that is winning of low pay, low sparing, low venture, low work and so forth and the rundown goes on. With high capital yield proportion, that is watched India needs high paces of ventures that would take and put forth jump forward in her attempts proceeds of achieving significant levels of development.

The significant highlights that is found in a venture are wellbeing of chief sum, liquidity, salary and its soundness, gratefulness and ultimately simple transferability. An alternate assortment of venture roads in plenitude and types are accessible, for example, shares, bank, organizations, gold and silver, land, extra security, postal investment funds. All the speculators contribute who wish to put, put their surplus cash in the previously mentioned roads that are accessible dependent on their hazard taking mentality and limit bearing. 


\subsection{Statement of the Problem}

This examination expects to put on some information with a concentration to realize the venture example of investors, factors considered while taking investment choices and to know how the venture fulfils the investors in the general public.

\subsection{Need of the Study}

The examination uncovers the connection between the financial aspects state of the investor and their inclination towards various methods of venture. This examination may mindful the individuals about the financial specialist's investor conduct dependent on their consistency of return. Step by step there is developing interest for riches the executive's capacities. It incorporates the comprehension of investors necessities and giving budgetary arrangement as indicated by it. Henceforth it becomes conduct and brain research.

\subsection{Objectives of the Study}

- To analyse the investment pattern among the Private, Government and Self-employed class investors

- To find out the factors influencing the investment decision of investors.

\subsection{Limitation}

The time factor was the fundamental impediment for finish of the examination, and the investigation was led focusing on the financial specialists in Bangalore city as it were.

The essential information has been gathered an organized survey to an example of 100 financial specialists in Bangalore city, which may not mirror the assessment of the whole population.

\section{LITERATURE REVIEW}

${ }^{1}$ Parimalakanthi and Ashok Kumar (2015) Is finished up from their examination that instruction of financial specialists is monstrously significant for the current day investors he has told. Investors, before making ventures, need to gather investment related data from the web and talk with companions, friends and financial specialists before making ventures. Most of the financial specialists want to put resources into investment account followed by Gold and Silver, Fixed store account and so forth. The result of the exploration has indicated that the greater part of the financial specialist's incline toward bank stores followed by interest in gold and silver venture.

${ }^{2}$ Ajay Singh and Dr. Rahul Sharma (2016) From the investigation it tends to be deduced that there exist an enormous extension for granting and completing the money related education for various segments of society to build up a knowledge for taking the powerful speculation choice by remembering the different characteristics that contributes toward the advancement of venture conduct. It additionally show that the monetary proficiency and mindfulness identified with different budgetary instruments can assist a speculators with taking a substantial educated choice for making sure about the money related fate of self and wards. The degree of information, level of premium and level of duty for monetary arranging process assumes an exceptionally critical job in life of each speculator which even give a gigantic extension in the interest of market controllers and furthermore for the benefit of organizations to spread the money related proficiency in an improved way with the goal that it help a financial specialist to get ready for future in an everlasting way.

${ }^{3}$ Dr. N. S. Pandey and P. Kathavarayan(2017) This paper is to look at the reserve funds and venture conduct of school employees in Puducherry area. This investigation manages financial specialists' inclination of Shares, Debentures, Mutual 
reserve, Bank stores and Life protection and so on. The centre target of this investigation is to discover sparing inclination of speculators about various venture roads. The impression of speculation and financial specialists' attention to venture roads have been investigated and deciphered.

${ }^{4}$ Arup Kumar Sarkar and Dr. Tarak Nath Sahu 2018 the examination is an investigation of speculation conduct of individual financial specialists of securities exchange to enquire whether there is any effect of three autonomous factors to be specific Demographic Factors, Awareness and Perceived Risk Attitude on just a single ward variable Investment Behaviour. The investigation has gathered essential information from 400 arbitrarily chose singular financial specialists of securities exchange from different areas of West Bengal utilizing an organized poll on five-point Likert scale. The investigation finds that the mindfulness levels of the individual speculators are on moderate level and money related mindfulness is more than social learning. Seen Risk Attitude is for the most part guided by Affect as opposed to Cognition. The examination show that Demographic Factors, Awareness and Perceived Risk Attitude fundamentally impact Investment Behaviour of individual financial specialists of securities exchange.

${ }^{5}$ Sachin Kumar Rohatgi and Dr. P.C. Kavidayal (2019) In their studythe budgetary situation of a nation to a great extent relies upon the expansion rate, outside conversion scale, per capita Gross local item, and so forth. Reserve funds from working class family units likewise assumes an indispensable job in improving the money related situation of a nation as it prompts more ventures and capital development in the economy. Reserve funds and ventures are straightforwardly proportionate to one another. There are various examinations directed right now the components influencing the sparing and venture designs, yet there is a shortage of writing accessible which appears, regardless of whether the financial specialists have had the option to accomplish their speculation objectives and the presentation of various speculation choices living up to their desires.

\subsection{Hypothesis of the Study}

The hypothesis of the study can be described here in as under:

- There is no significant association between the qualification of respondent and investment behaviour.

- There is no significant association between the occupation of respondents and objectives of investment.

- There is no significant association between the monthly income of respondents and factors influencing investment.

- There is no significant difference in the factors influencing among different age groups of the respondents.

- There is no significant difference in the factors influencing and occupation of the respondents.

- There is no significant difference between factors influencing and monthly income of the respondents.

\section{METHODOLOGY}

The current examination is a venture example of Private worker, Government representative and independently employed in Bangalore city. The examination territory is included by a decent number of salaried and expert who can spare and contribute. Furthermore, the examination region is highlighted with all the offices that are required for activating and 
transmitting the inactive investment funds. This exploration study is a distinct sort of research study. So as to lead this examination, 100 Investors in Bangalore city have been studied and survey is utilized for information assortment.

\section{Sources of Data}

All the information required for this reason has been gotten chiefly from essential sources, optional wellsprings of information have likewise been alluded.

\section{Data Collection Method}

The data collection method used to obtain the desired information from primary sources has been through survey and structured questionnaire has been used as an instrument.

\section{Sampling Plan}

Target Population: Investors in Bangalore City

Sampling Unit: An individual investor in Bangalore City

Sampling Method: Convenient sampling

Sample Size: 100

Area of Survey: Various localities in Bangalore city.

\section{Statistical Tools and Techniques}

For estimating different wonders and investigating the gathered information adequately and proficiently to make sound determinations, various factual methods includingANOVA, Cross tabulation and chi-square test for the testing of hypotheses have been used.

\section{Data Analysis and Interpretation}

\section{Qualification and Investment Behaviour}

Null Hypothesis: There is no significant association between the qualification of respondents and investment behaviour.

Alternative Hypothesis: There is no significant association between the qualification of respondents and investment behaviour.

\begin{tabular}{|c|c|c|c|c|c|c|c|c|}
\hline \multicolumn{9}{|c|}{ Qualification* Investment Behaviour Crosstabulation } \\
\hline \multicolumn{9}{|c|}{ Count } \\
\hline & & \multicolumn{6}{|c|}{ Investment Behaviour } & \multirow[b]{2}{*}{ Total } \\
\hline & & $\begin{array}{c}\text { Saving } \\
\text { Account }\end{array}$ & $\begin{array}{c}\text { Mutual } \\
\text { Fund }\end{array}$ & $\begin{array}{l}\text { Bond and } \\
\text { Debenture }\end{array}$ & Real Estate & Gold & Chit Fund & \\
\hline \multirow{3}{*}{ Qualification } & Under Graduate & 4 & 0 & 0 & 3 & 3 & 0 & 10 \\
\hline & Post Graduate & 38 & 3 & 0 & 0 & 13 & 16 & 70 \\
\hline & Professional & 3 & 6 & 4 & 0 & 0 & 7 & 20 \\
\hline \multicolumn{2}{|c|}{ Total } & 45 & 9 & 4 & 3 & 16 & 23 & 100 \\
\hline
\end{tabular}

\begin{tabular}{|l|c|c|c|}
\hline \multicolumn{4}{|c|}{ Chi-Square Tests } \\
\hline & Value & df & Asymp. Sig. (2-sided) \\
\hline Pearson Chi-Square & $69.092 \mathrm{a}$ & 10 & .000 \\
\hline Likelihood Ratio & 56.736 & 10 & .000 \\
\hline Linear-by-Linear Association & .091 & 1 & .762 \\
\hline
\end{tabular}




\begin{tabular}{|l|c|l|}
\hline $\mathrm{N}$ of Valid Cases & 100 & \\
\hline a. 13 cells $(72.2 \%)$ have expected count less than 5. The minimum expected count is.30. \\
\hline
\end{tabular}

The $\mathrm{p}$ value $(0.762)$ is higher than 0.05 hence the null hypothesis is accepted. There is no significant association between the Qualification of respondents and investment behaviour. An individual makes investment based on his occupation.

\section{Occupation and Objectives of Investment}

Null Hypothesis: There is no significant association between the occupation of respondents and objectives of investment.

Alternative Hypothesis: There is significant association between the occupation of respondent and objectives of investment.

\begin{tabular}{|c|c|c|c|c|c|c|}
\hline \multicolumn{7}{|c|}{ Occupation * Objectives of Investment Crosstabulation } \\
\hline \multicolumn{7}{|c|}{ Count } \\
\hline & & \multicolumn{4}{|c|}{ Objectives of Investment } & \multirow{2}{*}{ Total } \\
\hline & & Safety & Liquidity & High Return & Low Risk & \\
\hline \multirow{3}{*}{ Occupation } & Private Employee & 54 & 12 & 16 & 9 & 91 \\
\hline & Government Employee & 3 & 0 & 0 & 0 & 3 \\
\hline & Self Employed & 0 & 3 & 3 & 0 & 6 \\
\hline \multicolumn{2}{|r|}{ Total } & 57 & 15 & 19 & 9 & 100 \\
\hline
\end{tabular}

\begin{tabular}{|l|c|c|c|}
\hline \multicolumn{3}{|c|}{ Chi-Square Tests } \\
\hline & Value & Df & Asymp. Sig. (2-sided) \\
\hline Pearson Chi-Square & $14.621^{\mathrm{a}}$ & 6 & .023 \\
\hline Likelihood Ratio & 16.873 & 6 & .248 \\
\hline Linear-by-Linear Association & 1.333 & 1 & \\
\hline N of Valid Cases & 100 & & \\
\hline a. 8 cells (66.7\%) have expected count less than 5. The minimum expected count is.27. \\
The p value (0.248) is higher than 0.05 hence the null hypothesis isaccepted. There is no significant association \\
between the occupation of respondents and objectives of investment. An individual makes investment based on his \\
income. These incomes are gotten by him in visit interims as month to month pay on account of salaried, benefit on \\
account of business. So there exist a relationship among income and objectives of investment.
\end{tabular}

\section{Monthly income and Objective of investment}

Null hypothesis: There is no significant association between the Monthly income of respondents and objectives of investment.

Alternative Hypothesis: There is significant association between the Monthly income of respondent and objectives of investment.

\begin{tabular}{|c|c|c|c|c|c|c|}
\hline \multicolumn{7}{|c|}{ Monthly Income * Objectives of Investment Crosstabulation } \\
\hline \multicolumn{7}{|c|}{ Count } \\
\hline & & \multicolumn{4}{|c|}{ Objectives of Investment } & \multirow{2}{*}{ Total } \\
\hline & & Safety & Liquidity & High Return & Low Risk & \\
\hline \multirow{4}{*}{ Monthly Income } & Above 50,001 & 6 & 6 & 3 & 0 & 15 \\
\hline & Below Rs 15,000 & 4 & 0 & 3 & 0 & 7 \\
\hline & Between Rs 30,001-50,000 & 11 & 0 & 10 & 0 & 21 \\
\hline & Between Rs15,001-30,000 & 36 & 9 & 3 & 9 & 57 \\
\hline & Total & 57 & 15 & 19 & 9 & 100 \\
\hline
\end{tabular}




\begin{tabular}{|c|c|c|c|}
\hline \multicolumn{4}{|c|}{ Chi-Square Tests } \\
\hline & Value & df & Asymp. Sig. (2-sided) \\
\hline Pearson Chi-Square & $35.300^{\mathrm{a}}$ & 9 & .000 \\
\hline Likelihood Ratio & 39.970 & 9 & .000 \\
\hline $\mathrm{N}$ of Valid Cases & 100 & & \\
\hline $\begin{array}{l}\text { a. } 10 \text { cells (62 } \\
\text { From the above valu } \\
\text { objectives for which }\end{array}$ & $\begin{array}{l}\text { the less } t \\
\text { the Mon } \\
\text { ade. }\end{array}$ & inim & $\begin{array}{l}\text { cted count is.63. } \\
\text { hly significance for the }\end{array}$ \\
\hline
\end{tabular}

\section{ANOVA ANALYSIS}

\section{Age and factors influencing investment avenues}

\begin{tabular}{|c|c|c|c|c|c|c|c|c|}
\hline \multicolumn{9}{|c|}{ Descriptive } \\
\hline \multicolumn{9}{|c|}{ Factors influencing } \\
\hline & \multirow{2}{*}{$\mathbf{N}$} & \multirow{2}{*}{ Mean } & \multirow{2}{*}{$\begin{array}{c}\text { Std. } \\
\text { Deviation }\end{array}$} & \multirow{2}{*}{$\begin{array}{l}\text { Std. } \\
\text { Error }\end{array}$} & \multicolumn{2}{|c|}{$\begin{array}{l}\text { 95\% Confidence Interval } \\
\text { for Mean }\end{array}$} & \multirow{2}{*}{$\underset{\mathbf{m}}{\text { Minimu }}$} & \multirow{2}{*}{$\begin{array}{c}\text { Maximu } \\
\text { m }\end{array}$} \\
\hline & & & & & $\begin{array}{l}\text { Lower } \\
\text { Bound } \\
\end{array}$ & Upper Bound & & \\
\hline $\begin{array}{c}\text { Below } 30 \\
\text { years }\end{array}$ & 13 & 6.23 & 2.048 & .568 & 4.99 & 7.47 & 4 & 9 \\
\hline $31-40$ years & 64 & 2.63 & 2.380 & .298 & 2.03 & 3.22 & 1 & 8 \\
\hline $41-50$ years & 23 & 1.26 & .689 & .144 & .96 & 1.56 & 1 & 3 \\
\hline Total & 100 & 2.78 & 2.517 & .252 & 2.28 & 3.28 & 1 & 9 \\
\hline
\end{tabular}

Null hypothesis: There is no significant different between the age of the respondents and Factors influencing.

Alternative Hypothesis: There is significant different between the age of the respondents and Factors influencing.

\begin{tabular}{|l|c|c|c|c|c|}
\hline \multicolumn{7}{|c|}{ ANOVA } \\
\hline & Sum of Squares & df & Mean Square & F & Sig. \\
\hline Between Groups & 209.418 & 2 & 104.709 & 24.313 & .000 \\
\hline Within Groups & 417.742 & 97 & 4.307 & & \\
\hline Total & 627.160 & 99 & & & \\
\hline
\end{tabular}

The ANOVA result in the table shows that the calculated F-ratio value is 24.313 which is greater than the table value 0.000 . Since the calculated value is greater than the table value it is inferred that the preference about the investment avenues is significant among the age group of the respondents.Hence, the hypothesis is rejected.

\section{Occupation and Factors Influencing Investment Avenues}

\begin{tabular}{|c|c|c|c|c|c|c|c|c|}
\hline \multicolumn{9}{|c|}{ Descriptive } \\
\hline \multicolumn{9}{|c|}{ Factors influencing } \\
\hline & \multirow[t]{2}{*}{$\mathbf{N}$} & \multirow[t]{2}{*}{ Mean } & \multirow[t]{2}{*}{ Std. Deviation } & \multirow[t]{2}{*}{ Std. Error } & \multicolumn{2}{|c|}{$\begin{array}{l}\text { 95\% Confidence Interval for } \\
\text { Mean }\end{array}$} & \multirow[t]{2}{*}{ Minimum } & \multirow[t]{2}{*}{ Maximum } \\
\hline & & & & & Lower Bound & Upper Bound & & \\
\hline Private Employee & 91 & 2.82 & 2.567 & .269 & 2.29 & 3.36 & 1 & 9 \\
\hline \begin{tabular}{|l|} 
Government \\
Employee
\end{tabular} & 3 & 1.00 & .000 & .000 & 1.00 & 1.00 & 1 & 1 \\
\hline Self Employed & 6 & 3.00 & 2.191 & .894 & .70 & 5.30 & 1 & 5 \\
\hline Total & 100 & 2.78 & 2.517 & .252 & 2.28 & 3.28 & 1 & 9 \\
\hline
\end{tabular}

Null hypothesis: There is no significant different between the occupation of the respondents and Factors influencing. 
Alternative Hypothesis: There is significant different between the occupation of the respondents and Factors influencing.

\begin{tabular}{|l|c|c|c|c|c|}
\hline \multicolumn{7}{|c|}{ ANOVA } \\
\hline \multicolumn{7}{|c|}{ Factors influencing } \\
\hline Between Groups & Sum of Squares & df & Mean Square & F & Sig. \\
\hline Within Groups & 9.973 & 2 & 4.987 & .784 & .460 \\
\hline Total & 617.187 & 97 & 6.363 & & \\
\hline
\end{tabular}

The ANOVA result shows that the calculated F-ratio value is. 784 which is greater than the table value 0.000 . Since the calculated value is greater than the table value it is inferred that the factors influencing investment avenues is significant among the occupation of the respondents. Hence, the hypothesis is rejected.

\section{Monthly Income and Factors influencing}

\begin{tabular}{|c|c|c|c|c|c|c|c|c|}
\hline \multicolumn{9}{|c|}{ Descriptive } \\
\hline \multicolumn{9}{|c|}{ Factors influencing } \\
\hline & \multirow[t]{2}{*}{$\mathbf{N}$} & \multirow{2}{*}{ Mean } & \multirow{2}{*}{$\begin{array}{c}\text { Std. } \\
\text { Deviation }\end{array}$} & \multirow{2}{*}{$\begin{array}{l}\text { Std. } \\
\text { Error }\end{array}$} & \multicolumn{2}{|c|}{$\begin{array}{c}95 \% \text { Confidence Interval for } \\
\text { Mean }\end{array}$} & \multirow{2}{*}{ Minimum } & \multirow[t]{2}{*}{ Maximum } \\
\hline & & & & & Lower Bound & Upper Bound & & \\
\hline Below Rs 15,000 & 7 & 3.00 & 1.633 & .617 & 1.49 & 4.51 & 1 & 5 \\
\hline Rs $15,001-R s 30,000$ & 56 & 2.91 & 2.692 & .360 & 2.19 & 3.63 & 1 & 9 \\
\hline Rs 30,001-Rs 50,000 & 23 & 1.74 & 1.815 & .378 & .95 & 2.52 & 1 & 7 \\
\hline Above Rs 50,001 & 14 & 3.86 & 2.742 & .733 & 2.27 & 5.44 & 1 & 8 \\
\hline Total & 100 & 2.78 & 2.517 & .252 & 2.28 & 3.28 & 1 & 9 \\
\hline
\end{tabular}

Null hypothesis: There is no significant different between the monthly income of the respondents and Factors influencing.

Alternative Hypothesis: There is significant different between the monthly incomeof the respondents and Factors influencing.

\begin{tabular}{|l|c|c|c|c|c|}
\hline \multicolumn{7}{|c|}{ ANOVA } \\
\hline & Sum of Squares & Df & Mean Square & F & Sig. \\
\hline Between Groups & 42.457 & 3 & 14.152 & 2.324 & .080 \\
\hline Within Groups & 584.703 & 96 & 6.091 & & \\
\hline \multicolumn{1}{|c|}{ Total } & 627.160 & 99 & & & \\
\hline
\end{tabular}

The ANOVA result shows that the calculated F-ratio value is 2.324 which is greater than the table value 0.000 . Since the calculated value is greater than the table value it is inferred that the factors influencing investment avenues is significant among the monthly income of the respondents. Hence, the hypothesis is rejected.

\section{FINDINGS}

The qualification of respondents and their investment behaviour are no significantly associated i.e., the respondents' qualification influences their of making investment not significantly.

The occupation of the respondents and objectives of investment are no significantly associated i.e, the respondents occupation influences their of making investment not significantly

The Monthly income is having highly significance for the objectives for which the investment was made i.e the respondents monthly income influencestheir of making investment significantly. 
The ANOVA result shows that the calculated F-ratio value is 24.313 which is greater than the table value 0.000 . The age of the respondent and the factor influencing are no significantly different. Hence, the hypothesis is rejected.

The ANOVA result shows that the calculated F-ratio value is. 784 which is greater than the table value 0.000 . The occupation of the respondent and factor influencing are no significantly different. Hence, the hypothesis is rejected.

\section{CONCLUSIONS}

The examination depends on the investigation of investment among Private, Government and Self-employed financial specialists and it has been discovered that a significant number of the respondents are working in private segment. They incline toward for the most part in putting resources into okay venture roads. It is apparent from the examination that the greater part of the financial specialists is setting aside their cash for their children education, marriage and to satisfy different objectives of their life. There is an opportunity to expand the reserve funds and venture propensities among medium and high hazard roads and their investment relies on the yearly pay among the respondents. The investigation came about that higher pay bunch are putting more in their venture.

\section{REFERENCES}

1. Parimalakanthi and Ashok Kumar (2015); A Study on Investment Preference and behaviour of Individual Investors in Coimbatore Citonfring International Journal of Industrial Engineering and Management Science, Vol. 5, No. 4, December 2015.

2. Ajay Singh and Dr. Rahul Sharma (2016); Financial Literacy \& its impact on Investment Behaviour for Effective Financial Planning, IJRFM, Vol. 6, Issue 8, August 2016, pp. 50 63

3. Gill, Rupinder Kaur, and RubeenaBajwa. "Study on Behavioral Finance, Behavioral Biases, and Investment Decisions." International Journal of Accounting and Financial Management Research (2018): 1-14.

4. Dr. N. S. Pandey and P. Kathavarayan (2017); Empirical Analysis on Savings and Investment Behaviour of College Faculty Members in Puducherry Region; Pacific Business Review International Volume 9 Issue 7, Jan. 2017.

5. Dhamala, Gobinda, et al. "A research study on investors behaviour regarding choice of asset allocation of teaching staff." International Journal on Integrated Education 3.3 (2020): 126-135.

6. Arup Kumar Sarkar and Dr.TarakNathSahu 2018; Analysis of Investment Behaviour of Individual Investors of Stock Market: A Study in Selected Districts of West Bengal; Pacific Business Review International Volume 10 Issue 7, January 2018.

7. Fatima, Zertaj, and Mohd Akbar Ali Khan. "A Study of Behavioural Factors Influence on Investment Decision in Mutual Funds-Evidence in Public and Private Banks Mutual Funds." Sumedha Journal of Management 6.2 (2017): 62-74.

8. Sachin Kumar Rohatgi, Dr. P.C. Kavidayal, Dr. Krishna Kumar Singh (2019); A Study of Savings and Investment Patterns of Small Investors: A Literature Review, international journal of scientific \& technology research volume 8, issue 12, December 2019.

9. Totala, Sunita. "Investment Preferences of Salaried Persons of Indore." International Journal of Economics, Commerce and Research (IJECR) 6.2 (2016). 